\title{
The Late Spanish Translation of The Federalist Papers and the concept of Federalism in Argentina at the time
}

\author{
Rebeca Viguera-Ruiz ${ }^{1}$ \\ ${ }^{1}$ University of La Rioja, New York University, Spain \\ Correspondence: Rebeca Viguera-Ruiz, Departamento de Ciencias Humanas, Universidad de La Rioja, Calle Luis de \\ Ulloa 2, 26004 -Logrono (La Rioja, España), Spain.
}

Received: February 22, 2019

Accepted: March 15, $2019 \quad$ Available online: April 1, 2019

doi:10.11114/ijsss.v7i3.4188

URL: https://doi.org/10.11114/ijsss.v7i3.4188

\begin{abstract}
Throughout the second half of the $19^{\text {th }}$ century a process took place in Latin America in order to recover the original concept of federalism for the first time mentioned in the United States at the end of 18th century. This paper seeks to better understand how the Spanish translation of The Federalist-Argentina, 1868-would have been an attempt to look back at the North American model and to restore the original meaning of the concept, not only from the semantic perspective but also through its practical implementation as a political system in the specific case of Argentina.
\end{abstract}

Keywords: Federalism, Confederalism, El Federalista, Argentina, Latin America, translations, concepts

\section{Introduction}

It is generally agreed that after the process of independence from Spain, the Federation was the preferred political system in most of the Latin American countries as a form of National organization of the State. It was a system that sought an effective balance between the capacity of the provinces to elect their leaders or regulate their institutions and a strong central power governing the national life.

Along this process the North American example was always an outstanding reference among Hispanic politicians. Nonetheless, it was in practice more an adaptation of the concept of confederation rather than the assimilation of the federalism first designed by the founders of the United States Constitution.

In Latin America, most of the time, the Executive could in fact over-ruled the provincial powers, which means that a certain type of "centralism" had settled in political practice. This last approach was a real solution best suited to the specific needs of these territories during the first decades of the 19th century.

Just to mention briefly, we can say that the case of Spain is slightly different, as the French and English models remained very much present in its constitutions until the second half of the century. It was then that a strong interest arose from some sectors of radical liberalism, democrats or republicans in recovering the concept claimed by Hamilton, Madison and Jay in The Federalist.

In any case, what it is true is that in both cases, Spain and Latin America, a process took place throughout the second half of the 19th century in order to recover the original concept of federalism for the first time mentioned and defined in the United States (henceforth U.S.) at the end of 18th century. The goal was to restore the original meaning of the word, not only from the semantic perspective but also through its practical implementation as a political system.

For this purpose, a number of mechanism of action were launched to step up the level of public debate on this topic. Prominent among these had been the publication of articles in the press, the calls made in Parliament about this issue, or the proliferation of intellectual clubs and political gatherings. However, this paper will focus on another mechanism developed in Latin America to look towards the U.S. Federalism: This is the circulation of Spanish translations of The Federalist after 1868. This initiative was an attempt to look back at the North American federalism; a federalism that differs from the ones that Hispanic federalists had set up by mid century.

Taking these ideas into consideration, it is important to make it clear that this paper does not seek to analyze the concepts of federal/confederal or federalism/confederalism in the Latin American context at the time, but to reflect on how translations of outstanding works were an important tool to create new concepts as well as an important way to produce, circulate and spread out new political meaning of pre-existent concepts. In this particular case, the late Spanish 
translation El Federalista (Buenos Aires, 1868) will be analyzed, together with the structure of the text and some of its main characteristics in comparison with the original English version. This approach will let us better understand how, when, and why this work helped the North American Federalism to be regained in Argentina.

Many intellectuals and political representatives in that moment demanded a higher similarity to the U.S. model. $E l$ Federalista's edition and its distribution could have been crucial for contemporaries to understand the underlying essence of the concept and the model, to make them intelligible for both politicians and the common people. (Note 1)

\section{El Federalista, 1868: A Brief Conceptual Context}

Before starting to focus on the Spanish edition, we can just remember a couple of notes about the English original one. The Federalist is said to be one of the main works on politics that has been published in the United States of America. Written in 1787, it was a public defence of the North American Constitution and the Federal Government outlined by Alexander Hamilton, John Jay and James Madison. (Note 2) At the very beginning they were 85 letter signed by the pseudonym "Publius", in which the three authors defended a new Federal Government against the Articles of Confederation. (Note 3)

During the first half of the 19th century many new editions were published in English and translated to other languages; being the French translation the best known in Latin America at that time. (Note 4)

3/1788 (New York): 1st volume - 36 essays / anonymous

5/1788 (New York): 2nd volume - 49 essays / anonymous (Note 5)

1792 (Paris): 1st French translation - the authors' names were mentioned instead of the "Publius" pseudonym

1802 (New York): New Edition by George Hopkins - the authors' names were mentioned in general (not in each essay)

1810 (New York): Hamilton's ed. (Note 6) - Works of Hamilton - new edition in which the authorship of each essay first appeared according to Hamilon's notes

1818 (Indianapolis): Jacob Gideon's ed. (Note 7) - new edition in which different autorship of each essay was mentioned according to Madison's references

1826 (Maine): New ed., the numbers written by Mr. Madison corrected by himself

1863 (New York): Henry Dawson's ed. (Note 8) - attempt to recover the original essence of the 1st edition

From the mid 19th century onwards many copies of this work were reprinted both in English and other languages. (Note 9) Despite the existence of these early versions of The Federalist, the first Spanish translation was not published until 1868, in Buenos Aires, Argentina. (Fig.1) In order to better understand this late edition, its impact and relevance, a brief review is needed of the specific conceptual context in which it was issued.

Thinking in terms of the history of ideas, we can say that it is not only economy or politics what makes a country become established as a Nation. Language is also very important during the process of consolidation of a State. Pedro Luis Barcia states that three phases can be pointed out to study the political language evolution in Latin American during the 19th century: 1) the one developed during the foreign domination; 2) the one being experienced along the processes of independence; 3 ) and a third one reached after the independence. (Note 10)

Regarding the concept of Federalism, it is important to notice that the differences between the meaning of federation and confederation were not always clear in Latin America during the first half of the 19th century, nor even during the second half. Throughout the latter half of the 18th century the terms federative/confederative were very much understood as synonymous with alliance or union. However, the emergence of new political spaces during the 19th century involved a new debate about these terms. (Note 11) In that specific context, the concept federal/federalism began to be interpreted as a decentralized political system in contrast to confederal/confederalism referring to a more centralized one.

During the first half of the 19th century a new political order was trying to be tested in Latin America in order to satisfy public and political needs that arose after the independences. The mentioned debate around federalism/confederalism referred then to the need for the new political institutions to make it clear where the sovereignty should be based on. Sometimes both concepts were used with the same meaning. But some other times they referred different realities. (Note 12) The complexity of this set of meanings is the key to understanding the concept of federalism in that context. Using the same word some considered a more centralized system, while others referred to a decentralized one. 


\section{The Fideralist}

"EL FEDERALISTA.

$c$

ARTICULOS SOBRE

LA CONSTTTUCION DE LOS ESTADOS. UNIDOS

EScRITOS EN 1788 POI

Mr. HaVILTON, Mr. MADISON Y Hr. JAY

y correjidos por los nismos autores,

CoN UN APÉxnice

QUE CONTIENE LOS ARTíctios DE CONFEDERACtoN

y La Constitucion de los_E. U.

TRADOCCION HECIIA DEL TEGTO INGLBS POR J. M. OANTHLO.

BUENOS AIRES

Impreata del Sigwo, Victoria 151. 1868

Figure. 1. Front cover of El Federalista, 1868

Despite such differences, the federation was more commonly understood as a decentralized political system which represented a good balance between the powers in the provinces and the State. In order to find this balance, the North American federal system was considered a perfect model to follow. Many individuals stood up for it and many others criticised it. The latter thought that it was too difficult to adapt the system in Latin America, as the differences between both spaces were enormous.

Whereas this federalism referred to a political agreement between local and national powers, the word or concept confederalism referred more specifically to the free association of independent and self-governed territories. This little difference affecting the meaning of the two terms was the starting point for a whole new debate around the level of centralism the National Federal State should practice. And it was a debate mostly developed during the central decades of the century onwards.

And, considering that the differences of meaning between the pairing federation/confederation were not clear during the century -neither in Latin America, nor in Spain-, perhaps it is possible to say that the Spanish edition of The Federalist, El Federalista, would have been an important tool used in political debates for those who defended the North American dual federalism as the best federal system to be definitely set up in these territories by the end of the siecle; or at least in Argentina.

\section{The Spanish Edition of The Federalist}

As previously suggested, it is necessary to think about translations as a key vehicle through which to spread ideas in the 19th century. New concepts emerged during this century but also traditional concepts were redefined as a result of new political contexts around the western world. That is why we should understand El Federalista as an attempt to circulate the ideas and concepts reproduced in its pages through Latin America and Spain. 


\subsection{Specific Historical Context \& Formal Text Features}

The first complete Spanish edition of The Federalist that has been documented is the translation by José María Cantilo, in Buenos Aires 1868. At that time the argentinean federalism was become established. During the precedent decades the North American experience was the most claimed reference. However, the former still had a long road ahead to achieve the level of decentralization required to be like its referent. Politicians in Argentina needed to find the best political balance between the model from the U.S. and the particular necessities among argentinians. It was believed a need to find this balance not only just after the emancipation, but throughout the whole 19th century.

The Constitution of Argentina was proclaimed on May 1, 1853, supported by all provinces except Buenos Aires. The latter would joined the Argentinean Confederation after the Pact of San Jose, which was signed in 1859. (Note 13) This Constitution gave shape to the Republic of Argentina and organized a federal, republican and representative national government. It was a republican system based on the principle of separation of powers which granted important legal and political capacities to the provinces at the same time that the Federal Executive needed to act under Congress supervision. This was, at least, the theory written down in the Constitutional text.

However, the real Argentinian federalism developed into a strong centralized system very different from the one established in the United States. From the 1860s on, several constitutional changes occurred that tried to get back to the North American model in order to minimize the control of the State over the provinces. (Note 14) Anyhow the debates continued between those who defended this latter option and the ones who just wanted the things stay the way they were.

This was the historical context in which El Federalista was published. It was also the context personally experienced by its author, José María Cantilo.

He was born in Buenos Aires, Argentina, on 14 December 1816. Initially, he studied chemical sciences and worked as a pharmacist while living in exile in Montevideo. After this experience, he became dedicated to literature and journalism, and he actively collaborated in El Comercio del Plata, El Siglo, El Correo del Domingo, La Verdad, El Nacional, El Talismán, El Tirteo and El Caduceo. (Note 15) Once back in Buenos Aires worked as the Secretary of Dr. Dalmacio Vélez Sársfield and took part of the Convención del Estado de Buenos Aires in 1860.

In addition to these experiences, it is important -to the aim of this work- to focus on Cantilo's political background. He was twice a parliamentary representative of Buenos Aires: first in the term 1862-1866 and second in the term 1872-1876. (Note 16) He addressed participative discussions while in politics; among those which can be highlighted was the claim for a federalism more similar to the one in the U.S. He perfectly knew the North American constitutional principles, its legislative structure and judicial procedures. A proof of this can be his translations into Spanish in 1863 of two works by Joseph Story: Commentaries on the Constitution of the United States, and The Constitutional Class Book: Being a Brief Exposition of the Constitution of the United States. (Note 17)

In 1862 the first legislative congress since 1810 took place in Argentina. It was the time when the debate around centralism in the argentinean federalism was re-opened in this country. At that time Cantilo was trying to defend the North American federal system as suitable for Argentina. (Note 18)

Many deputies, as him, agreed with the following idea: it was true that Argentinian federalism had need to be adapted at the very beginning to the whole new political situation after the independence. However it was time by the mid 19th century to take a step forward and adopt a more accurate federalism, as the one being practiced in the United States. These representatives usually reflected on the idea that every time the Constitution of Argentina did not follow this model plenty of problems and errors occurred. (Note 19)

That is why they thought that the solution to political problems in Argentina lied on imitating the North American federalist model and forgetting about the centralist one. To this effect, they claimed The Federalist to be a required reading to all wisdom men. It was said to be a precious book which contained the most exact federal doctrine. (Note 20) Both, federalist and centralists (federalistas y unionistas), agreed with that. They just dissented about where the equilibrium was based on between public local powers, provinces' powers and the power from the Federal Executive.

Taking this into consideration, it makes sense that the translation into Spanish of that book was considered crucial to spread out their ideas across Latin America and, most significantly, in Argentina. The U.S. Constitution had been a model, but it was time to focus on its particular federal system. By publishing this volume, El Federalista, Cantilo was claiming the need of copying the North American original model to recreate in Argentina its federal political principles. His own words about this issue were: "to men who recognize the Republic to be one of the best political system possible, it is required to learn from the United States example. There, in the United States, it has been triumphant consolidated". (Note 21) Perhaps other republics were not successful at all, but the one experienced in North America was, and that is why it was a perfect reference for them. (Note 22) 
This was the ideological content of Cantilo's speeches in Congress about this topic. He was always in favour of "imitating" the original North American federal system, both in making the laws and in organizing the administration. (Note 23) From his point of view it just required to start up in practice what it was enshrined in the Constitution.

It was barely two years after finishing his first experience as a Parliamentary Representative when El Federalista was printed in Spanish. This edition was published as a single volume of 736 pages -instead of two as the first English version. (Note 24) The translation is practically literal, it maintains the original meaning of the words and terms used and its author removed the signature "Publius" to identify the specific author of each essay.

Together with these points, there are some notable differences between the English and Spanish editions. The first one that can be pointed out is the different structure of the table of contents. (Figs. 2-3) The Spanish version met editorial principles commonly accepted during the 19th century: it is that you can see under the same title several of the articles about one same topic at the same time as a brief explanation about their contents.

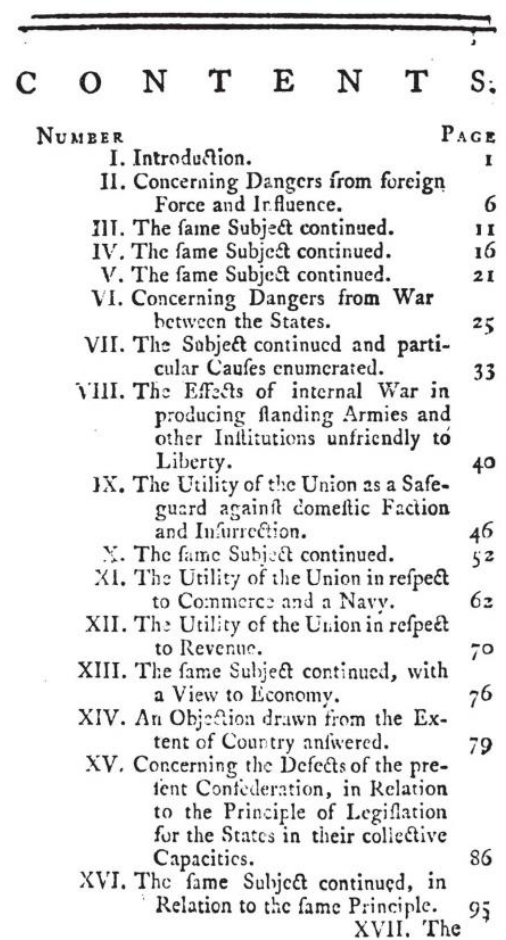

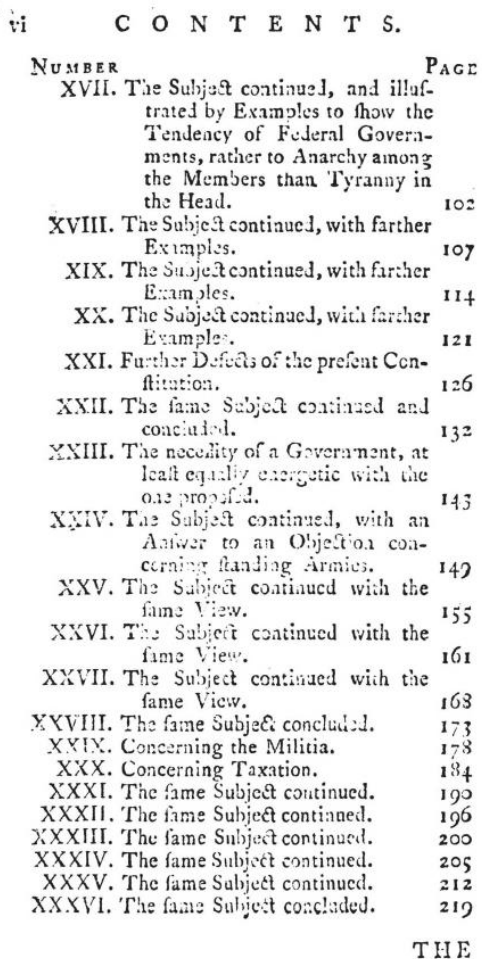

Figure 2. Table of contents of the English original version 


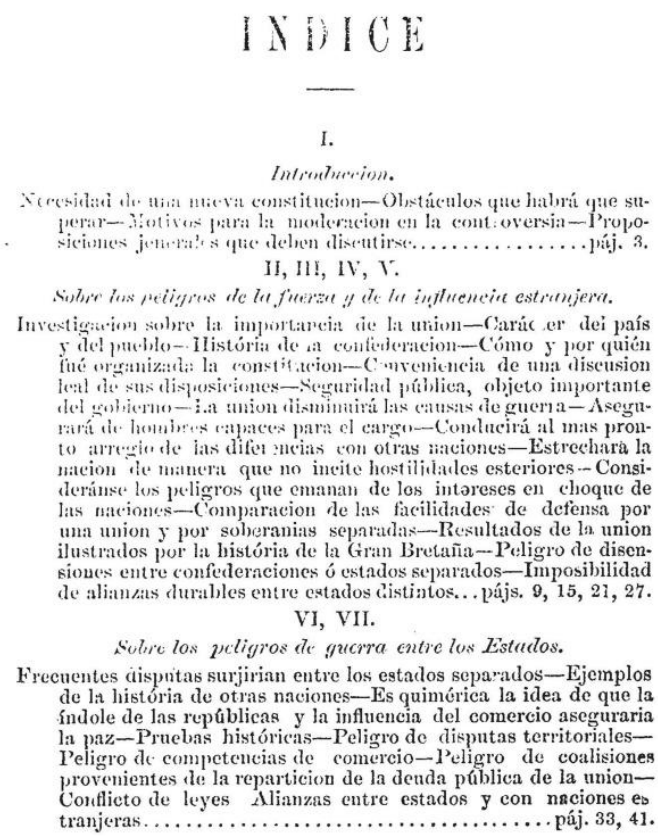

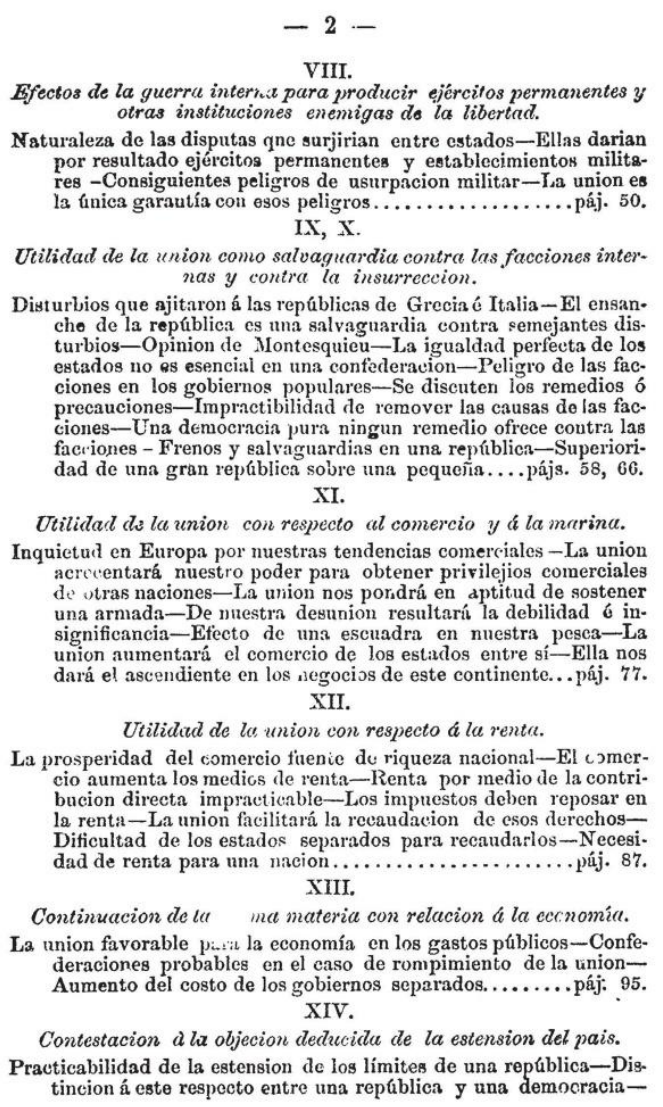

Figure 3. An example of the table of contents of the Spanish translation in 1868

It is also remarkable that the Spanish text included -throughout the last pages- the Articles of Confederation (1777) just before the Articles of the Constitution (1787). The Amendments to the United States Constitution were also included in the Spanish book whereas they did not appear in the English one. (Note 25) (Figs. 4, 5 \& 6)

Last but not least, a brief comment on the wording can be considered. As shown in the pictures, the paragraphs were subdivided in the Cantilo's edition to make it easier the reading and understanding of its content for Spanish readers. (Figs. 7-8) All the ideas are there and are the same, but they appeared broken down according to the readers' preferences. 


\section{ARTICUTOS ORIJINARIOS DE CONFEDERACION.}

A todos aquellos i quienes las presentes llegaren-Nos los abajo firinados, delegados cle los estudos anexos ì nuestros nombres, enviamos salud.

Por cunato los delegados de los Estados Unidos de Amériea reunidos en congreso el 15 de Noviembre del año de nuestro señor 1777, y segundo de la independencia de América, hemos convenido en ciertos articulos de confederacion y perpetua union entre los estados de Nueva Hampshire, Massachusets Bay, Rhode Island y Plantaciones de Providencia, Comnecticut, Nueva York, Nueva Jersey, Pensilvania, Delaware, Marilandia. Virginia, Carolina del Norte, Carolina del Sud y Jeorjia, en los términos siguientes:

\section{Articalog de confederacion y mépetua union en- tre Ios Estaños. (Los arriba nombrados.)}

Arr I-El titulo de esta confederacion será "Los Estados Unidos de América."

ArT II.-Cada Estado retiene su soberania, libertad 6 independencia, $y$ todo poder, jurisdiccion y derecho, que por esta ccnfederscion no están espresamente delegados á los Estados Unidos reuni dos en congreso.

Art. III-Los dichos estados por las presentes entran separadamente en una liga tirme de amistad entre sí, para su defensa comun, seguridad de sus libertades, y mútuo y jeneral bienestar; obligándose á auxiliarse entre si contra toda fuerza 6 ataque hecho á ellos 6 alguno de ellos por causa de relijion, soberania, comercio 6 cualquier otro pretesto.

Art. IV-Para mejor garantir y perpetuar la amistad mútua y las relaciones entre el pueblo de los diferentes estados de esia union. los habitantes libres de cada uno de ellos, con escepcion de los pobres, vagabundos y fujitivos de la justicia, gozarán de todos los privilejios é inmaunidades do ciudadanos libres en los varios estados; y el pueblo de cada estado tendrá libre entrada y ealida de mo para otro estado, y gozará en ellos de todos los privilejios de tráfico y comercio, sujeto a los mismos derechos, imposiciones y restricciones que los habitantes de oada uno respectivamente, con tal que esas restricciones no se estiendan hasta impedir la remocion de la propiedad importada de un estado á otro estado del cual sea habitante el dueño; con tal igualmente que no se establezca por ningun estado imposicion, derechos 6 restricciones sobre la propiedad de los Estz. dos Unidos 6 de alguno de ellos.

Si alguna persona culpable 6 acusada de traicion, felonía a otro alto crimen en algun estado huyese de la justicia y fuere hallada en alguno de los Estados Unidos, será á peticion del gobierno $\delta$ poder ejecutivo del estado de donde huyó, entregada y removida al estado que tenga jurisdiccion de su delito.

Fn cada uno de estos estados se dará entera fó y crèdito á los rejis-

Figure 4. First page of the Articles of Confederation in the Spanish translation of The Federalist 


\section{CONSTITUCION}

III) 1.0.

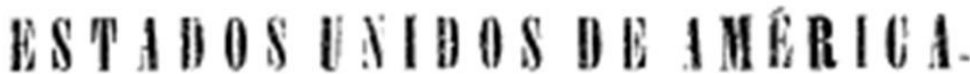

Nis, el pueblo de los Eatados Ínidos, won ol sirjeto de formar una ution toas perfectn, establecer la jnsticia, consolidar la paz doméstica, provecr á la defensa comun, proueover el bien. estar jeneral, $y$ asegurar los benefieios de la libertad para nos. otroe y para nuestra posteridad, ondenamos y pstablecemos esta Constitucion para los Estados Unidos de América.

\section{ARTICULO I.}

Sys. L.-Todas las atribuciones lejislativas yque por estu Cons. titucion se conceden residirán en un Congreso do los Estados Unidos, el cual so compondrá do un senado y de una cámara de representanter.

Sxe. II,-1. La cámara de representantes se compondrá de miembros elejidos cada dos años por el pueblo de los varios estados, y los electores de cada estado tendrán las cosdiciones que se requicren para ser electores de la rams mas numerosa de la lejielatura dol étado.

2. Para ser representante se requiere, haber cumplido veinticinco años, haber sido siete años cindadano do los Estados Unidos, y hallarse, al tiempo de su eleecion, residivado en el est sdo en que fuese elejido.

\section{7}

Figure 5. First page of the Articles of the Constitution in the Spanish translation of The Federalist 


\title{
ENMIENDAS
}

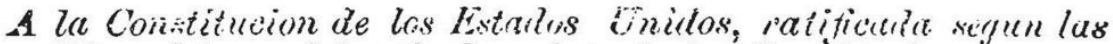
Disposiciones rlat articulo quinto de la Comstitucion que precede.
\end{abstract}

Arr. I. - El Congreso no podrá hacer ninguna ley estableciendo una relijion, ó prohibiendo el libre ejercicio de ninguna, ó restrinjido la libertad de la palabra, ó de la prensa, ó el dere. cho del jueblo para reunirse pacificamente $y$ para pedir justicia al grobierno.

An'r. II.-Siendo necesaria una milicia bien arreglada jesa la seguridad de un estado libre, no podrá coartarse al puelblo el derechi, de tener y llevar armas.

A к'T. III.-E Eu tiempo de paz no polrá ser alojado ningun soldado en ninguna casa sin el consentimiento de su ducño, ni tampoco en tiempo de guerra sino en la furma prescrita por la ley.

Art. I $V^{T}$. No se violari el derecho del preblo que le asegure contra rejistros y embargos arbitrarios en sus personas, domicisio, papeles y efectos; y no se espedirá ningruna órden sinó sobre - causa probable, apoyada con juramonto ó ativinacion y describiendo con particularidad el lugar que deba se: rejistrato $y$ las personas ó cosas que deben ser embargadas.

Ar'r. V.- Nadie estará obligado á contestar cargus sobre un crímen capit:.l, ú en cialquier medo infar'unte, sitio por denuncia ó aunsacion ante un gran jurado; esc o en los casos relativos á lis fueryas de mar y tierra, ó á la ilicial estando en servicio artivo en tiempo de guorra, ó en eas, de pùblico peligro : nadie estarí s!jeto á comer dos veces el riejgo de perder la vida 6 algun miembro pse el mismo deilto: ili estarí coblimalo en ningun: santi oriminal á ser testigo contra símismo, ni será priva is de la vida, la libertad, ó la propiedad, sin las formali-

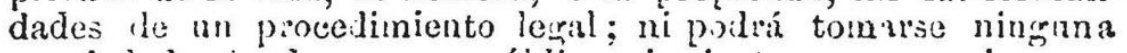
propielad privada para uso público, ein justa cempensacion.

ArT. Vl.- En todas las causas criminalea tendrá el acnsado el derectio de qlie se le jazirue pronta y públicamente por un jurado imparcial del estado y distrito en donde haya sido cometido el delito, $y$ cuyo distritu haya sedo antes fijado por la l ey, y á ser informariu de la naturaloza y causa de la acusacion y á ser careadu con lus testigos que declaren contra él ; á tener medios compulsorios para obtener testigos á sn favor y á tener el anxilio de abograto en su defensa.

Arr. VIr.-En las calisas civiles en que el valor que se cuestiona no esceda de veinte pesos, serí manteniào el derecho á ser juzgado por jurados; y ningun hecho: juzgado por un jurado

Figure 6. First page of the Amendments to the U.S. Constitution in the Spanish translation of The Federalist 


\section{EL FEDERALISTA.}

NÚNERO I

\section{POR ALEJANDRC HAMILTON.}

introltccion.

Despues dè una completa esperiencia de la incapacidad del gobierno federal existente, sois ahora llamados á delibexar sobre una Nueva Constitucion para los Estados Unidos de América. El objeto en sí manifiesta su propia importancia; comprendiéndose en sas efectos nada ménos que la existencir de la UNION, la seguridad y bienestar de las partes de que se compone, y la suerte de un imperio, bajo muchos respectos el mas importante del mundo.

Se tha observado con frecuencia, que parece haber sido reservado á este pueblo el resolver con su conducta y su ejemplo, la importante cuestion de si las sociedades humanas son en reálidad capaces ó nó de fundar un buen gobierno por la reflexion y la eleccion, $\delta$
T H E

\section{F E D E R A L I T T:}

ADDRESSED TO THE PEOPLE OF THE STATE OF
NEW-YORK.

N U M B E R I.

Introduction.

A FTER an unequivocal experience of the ineffiA cacy of the fubfilting federal government, you are called upon to deliberate on a new conftitution for the United States of America. 'The fubject fpeaks its own importance; compreherding in its confequences, nothing le?s than the exiftence of the UNION, the fafety and welfare of the parts of which it is comFofed, the fate of tin cimpire, in many refpects, the molt interefting in the world. It has been frequently semarked, that it icems to have been referved to the people oi this country, by their conduct and cxample, to decide the inportint queit on, whether focieties of men are really capobie or not, of ettabisthing good grovernment from reflection and choice, $c_{r}$ whether they are $f(r e v e r$ detine $d$ to depend, for their political confitutions, on accident and force. If there be any truth in the remark, the crilis, at which we are arrived, m.sy with propriety be regarded as the sera in which A

that

Figure 7. An example of the paragraphs in the Spanish version (left) and the English one (right) 


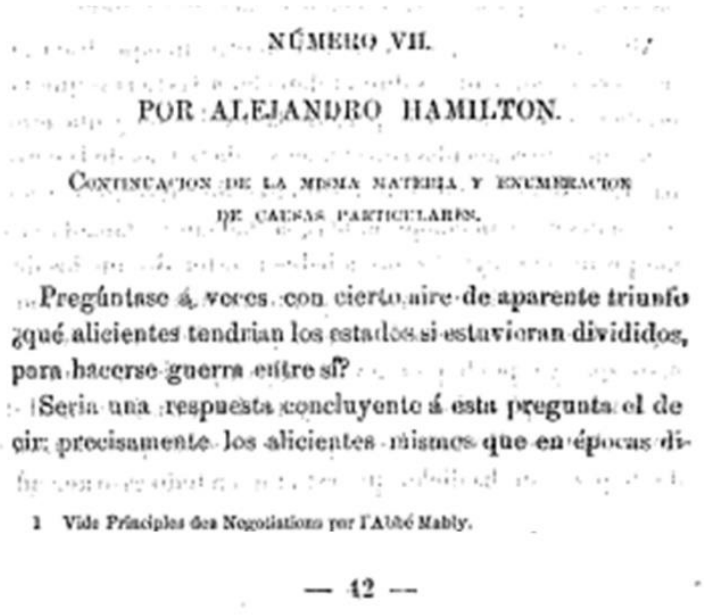

- vervas han anegado en sangre á todas las naciones dol mutido.

Pero desgrnciadamente parn nusotros, h enestion ad. mite wia rospuesta max especial. Hay causas de desanuer. do ante nuestra contemplacion inmediata, de enya tenden. eir, aun con las restricciones de nua constituoion federal, hemos tonido esperiencia suticiente que nor pone en ap. titud de formar juicio eobro lo que so podria esperar si so removiesen esas restricciones.

Las disputas sobre territorio han sidu en todn tiempo miradas como una de las fuentes mas fértiles de hostilidad entre las naciones. Talvex la mayor parte de las guerras que han desolato la tierra.reconocen eso orijen.

Esta causa existiria entre nosotros en toda su fuerza. Tenemos ana vist: porvion de territorio indeterminalo dentro de los Estados Unidue. Todavia hay redamos pendientes'entre varios de ellos; $y$ la disolucion de la Uaion daris motivo paru igaales reclamaciones entre torlos.

Bien sabido es que ha habido en otro tiectopo diseusio. nes sérias y animadas sobre el derecho á las tierras que no

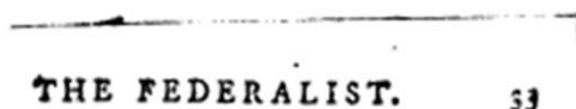

THE FEDERALIST.

\section{N U M B E R VII. The Sulject continucd and farticular Caufes enunicratcd.}

$I^{\mathrm{T}}$ $T$ is fometimes afked, with an air of fecming triumph, what inducements could the itates have, if cufuaited, to make war upon each o:her ? It would be a fuli anfwer to this queftion to fas - precitely the fame inducements which have, at diffitent times, deluged in blood all the nations in the werld. Lut anfortunately for us, the queftion aumits of a more particular aniwer. There are caufes of difference within our immediate contemplat:on, ot the tendency of which, cren under the reftraints of a tederal conttitution, we have had fufficient experience to enabie us to form a judgment of what might be expected, if thote reftraints were semoved.

Territorial difputes have at all times been found one of the mott fertile fources of hoftility an.cng nations. Perhaps the greatelt proportion of the wars that have delolated the earth have fprung from this origin.'This caufe would exitt, among us, in full torce. We bave a vaft tratt of unsettled territory within the botindaries of the United Statcs. I here titil are difcordant and undeciced claims between several of uein ; and the diflolution of the union would lay a founuation for fimilar claims between them all. It is well known, that they have heretolore had terious and ani. mated difuftions concerming the right to the lands which v.ere ungranted at the time of the ievoiution, and which ulually went uider the name of cruwnbunds. The lates within the limits of whoic coionial goveruments they were conpried, bave ciaimud them as their property; the otiaer, have cuntended that the rights of the cruivn in this article cevolved upon the union; efpecially as to all that par: of the Weftern territory which, either by actual pofieflion, or through the fubmifion o! che Indiun gropracturs, was abjected

Figure 8. Second example of the paragraphs in the Spanish version (left) and the English one (right)

\subsection{Significance of the Spanish Edition in the Latin American Context}

George Washington had already said about The Federalist that it should be a work mentioned by all future generations. (Note 26) There is no doubt that it was a reference for those who wrote the National Constitution of Argentina, for those who designed the political system of other Latin countries in the 19th century and for many Spaniards who looked at the United States as an example of social civil rights and political progress.

From the 1860s on Argentina longed for a political progress inside its limits, a progress ideally based on a more decentralized federalism. On this purpose, El Federalista would have given the Spanish people -both in South America and Spain- a deeper perspective of the North American federalism. It is important to notice that readings in their native language are always easier to understand. As Gadamer said: to understand historical sources they need to be translated into each native language of anyone who can consult them. (Note 27)

In fact, Cantilo himself wrote that his translation was thought up for being a useful book on liberty principles among the argentinians. He sought "el deseo de que se familiaricen en el país, especialmente entre la juventud estudiosa, aquellos libros en que pueda estudiarse con fruto la sabia organización política de la Gran República que ha servido de modelo a la nuestra". (Note 28) He stated that it was a complete version of The Federalist and that its final purpose was actually to implement the U.S. political system that had been once the model for the Republic of Argentina. (Note 29)

These are the reasons why El Federalista keeps the original meaning of the terms and concepts. And that is what explain the new structure of the ideas in paragraphs that are a little bit different from the ones in the English version. The new distribution was designed for being more accessible, easier to understand by Spanish readers. The final 
purpose of the book was pointing out the roots and foundations of the North American federalism, so that new readers could understand it without any problem.

Again, it is important to notice that a translation itself is in fact a process through which a new intellectual sphere can be constructed; a new scope where make it understandable the meaning of some concepts created or appeared in the past. These concepts would have been easily learned by contemporaries in the past, but can be more difficult to understand for new generations who lived in a very different social - economic and political context. (Note 30)

These reflections lead us to think about the Cantilos' edition as an effort to refocus the attention of Spanish people towards North American constitutional and federal principles. This would have then been the reason why he subdivided different contents or pages into shorter and more understandable paragraphs and why he adapted the table of contents to the new format generally used during the 19th century. The latter decision sought to point out the main contents of each article in the book: each title contains a synopsis of each subject and emphasizes the most valuable principles of the Federal Government that arose in 1787 in the U.S.

All these little adaptations could have been made to provide Spanish readers a better understanding of the text. These readers were not only able to read the essays of The Federalist, but also the original Articles of Confederation of the U.S. together with the Amendments. Both, the Articles and the Amendments had been translated into Spanish before that date, but it was in 1868 the first time a Spanish reader could read all of them in the same book: The Federalist articles, the Articles of Confederation, the Articles of the Constitution and the Amendments. It was the first time native Spanish readers could read the texts without anyone else's interpretation but themselves.

José Maria Cantilo himself wrote, in 1868, that his translation intended to show in Spanish all the contents included in The Federalist, a key book for the construction of the Federal Constitution of the United States of America by the end of the 18th century. "It was one of the most amazing and important sources to explain the Constitution", a work "fairly appreciated and valued" even in those late days. (Note 31)

It already had been a central reference during the sessions in Congress and throughout the argentinian press; and Cantilo was sure it would also be an essential reference in the future.

\section{Notes on the Circulation of El Federalista During the Last Decades of the $19^{\text {th }}$ Century}

The debate about the pairing federal/confederal or federation/confederation appeared in the U.S. when they were trying to build the nation as a Federal government, and it implied a kind of commitment in which the National Government shared its power with the different State Governments, at the same time the Union -I mean here a political and administrative Union- was preserved.

This was the goal for many Latin American governments at the beginning of the 19th century. Politicians and intellectuals were trying to succeed in setting up Federal Republics; and most of them took as their main reference the model from the U.S.

\subsection{El Federalista Throughout Latin America}

During the first decades of the 19th century the circulation of The Federalist -the English version-, was very limited in Latin America. Actually, the first specific reference appeared in the Gazeta de Buenos Ayres in 1816. (Note 32) But, anyhow, just the English and French editions were known by then. This can be surprising, as other works defending the North American Constitution were known and circulated by that time.

Regarding the Spanish version from 1868, it is possible to state that it was well received and somehow widely circulated. The next Spanish translation by Ildefonso Isla (Buenos Aires, 1887), (Note 33) was also well -or even betterreceived by the end of the century. In any case, the most circulated Spanish version of The Federalist would have been the Mexican one printed in 1943. (Note 34)

We can not be sure about the exact number of printed copies of the first edition in 1868. It is probably that around 800 to a thousand copies could have been circulated. This number can be worked out by taking into consideration some references from Congress sessions in that year. During the session on July 29, 1868, deputy Ocampo talk about this new book: El Federalista. He said it should be circulated among educated men in the country to spread out its contents as much as possible. Although it was firstly suggested to purchase 50 copies, deputy Quintana asked to buy at least 500 to be circulated all over around the country. This imply the existence of a higher number of printed copies. Everybody else agreed with him. (Note 35) And, although financial problems made Senate to oppose the purchase, it is at least important to take into account the initiative. (Note 36)

It was an initiative addressed while they were discussing about the federal structure of the State in Argentina. The North American model was again claimed to be the best reference against the anyhow invasive centralism that had been established in the country. The Constitution of Argentina was written on the theoretical basis of the Federal Constitution 
of the United States. But, as said before, it was necessary to go beyond the theory and apply it in practice without forgetting about the specific argentinian problems, customs and history. (Note 37)

To this effect the circulation of El Federalista was then important, as it had been before the circulation of other related works such as John Norton Pomeroy's, An introduction to the constitutional law of the united-states, Kent James' Commentaries on the American Law, or Edouard Laboulaye' Political History of the United States. (Note 38)

In that specific context Argentina was trying to become a strong independent Nation. By 1868 argentinians were struggling in favour of the federal republican cause: a war was taking place against Paraguay, several internal problems arose among different political parties and it was clear that new efforts needed to be addressed to guarantee political order. (Note 39) And a similar situation could have been experienced in many other Latin American countries.

By the mid 19th century the concept of federalism was related to that mentioned debate between establishing strong independent powers within the provinces or a strong National Executive which tended to overruled them.

The circulation of the Spanish edition, El Federalista ${ }_{s}$ indicates the willingness to copy the model of the U.S. and put its theories into practice. It was a reference of progress, prosperity and principles of liberty, equality and civil rights. It was considered the best model of representative government possible.

Thereby, it is possible to find hardcopies of El Federalista in Venezuela and Colombia, where the circulation of the 1868 edition was followed by the one published in 1887. It is fair to say that the latter was more well-known than the former, and that other works were more commonly discussed as the one by Tocqueville, La Democracia en América. In Chile, for instance, it was not until the last decade of the 19th century that the 1868 copy was more widespread. In Mexico, The Federalist was widely circulated during the 30s and mid 40s. When the U.S. conquered Texas a great rivalry arose between the two countries and politics from the States stop being considered a model until the following century.

It is clear that, without even being the most debated or circulated work, The Federalist and El Federalista were well known in Latin America during the 19th century. Nevertheless, one could well ask what the actual social impact of the work may be. It is unlikely that the different English or French editions would have been widely circulated among middle-working and lower classes during the first half of the century -nor even during the second half-, because of the illiteracy of most of the population. Intellectuals or politicians could have been the main recipients. That is why the Spanish edition is so important: it was printed at a time of remarkable development of the press and public opinion in Argentina, and it would had let many people to read the book in their native language and understand its contents.

\subsection{The Federalist and El Federalista in Spain}

Some intellectuals in Spain could have known and read The Federalist at the beginning of the 19th century, when Constitutional project of 1812 was being discussed. However, it is unlikely that it began to be familiar among politicans or intellectuals before the $1860 \mathrm{~s}, 1870 \mathrm{~s}$ or even 1880s. (Note 40) Federalism in a republican government was not conceived as a practical or possible solution to all political and monarchical problems experienced in Spain since the first decades of the century.

The constitution of the U.S. described a Republic and a federal decentralized government. And it was extremely incompatible with the strong monarchical and royalist Spanish tradition. Spanish people was not prepared for that change, and they would not be prepared for many years. This is why it makes sense that The Federalist -both in English and in Spanish-, had a wider circulation in Latin America than in Spain.

Actually, in Spain, it was not before the Revolution of September in 1868 that the federal option was taken into consideration as a model of government to solve the problems generated after Isabella the 2nd was "invited to leave" the country. (Note 41) Just after this happened a new period began when the debate arose between those in favour of the monarchy and those in favour of a Republic. That would have been the moment in which the North American model began to be a reference and a model to follow.

Regarding the circulation of El Federalista, we must say that in Spain they were very few who read or circulate it. The people had no political education, knew nothing of republican institutions, and the first hardcopy to be registered in a public library was the one in the National Public Library in 1874. (Note 42)

It would be after the Restoration of the monarchy by the end of the 19th century when republicans and federalists become stronger in Spain. And together with The Federalist, other works would have been their models to follow: Studies on the Constitution of the United States by Guichot, or Popular history of the United States edited in Barcelona in 1873. U.S. began to be a model of federalism, but The Federalist never was as widely known or circulated throughout Spain as it was throughout Latin America during the 19th century. 


\section{Discussion}

Different authors have demonstrated that many other works defending the U.S. Constitution were well known in Latin America during -and just after- the period of independence. And many of these works were translated into Spanish early that century. However, very few people read The Federalist, and it was not until 1868 that it was translate into Spanish for the very first time.

It is important to relate the edition of El Federalista in 1868, both to the socio-political context in Argentina at the time and to the political agenda of its author, José María Cantilo. During the first half of the century it was more important in Argentina to draw and adopt a Constitution than to discuss about the level of centralism addressed by the Executive. Actually the National Constitution of 1853 defined a Confederation rather than a Federation. It is only by taking into consideration the re-emerging debate around federalism/confederalism during the 60s that we can understand this Spanish translation by Cantilo.

He perfectly knew the North American Federalist model, and he was in favour not only to take it as a reference but to imitate it in Argentina. On his political agenda Cantilo always defended it was possible to follow the U.S. model for the argentinian case. And this is why the Spanish translation of The Federalist needs to be understood as part of his political and ideological strategy.

\section{References}

Adair, D. (1974). Fame and the Founding Fathers. Indianapolis: Liberty Fund.

Ávila, A. (2002). En nombre de la Nación. La formación del gobierno representativo en México. México: CIDE Taurus.

Ávila, A. (2002). Federalismo. México. In Fernández Sebastián, Diccionario político y social del mundo iberoamericano. Madrid: Fundación Carolina / Sociedad Estatal de Conmemoraciones Culturales / Centro de Estudios Políticos y Constitucionales.

Barcia, P. L. (1875-1879). Diccionario del lenguaje argentino. Buenos Aires: Academia Argentina de Ciencias, Letras y Artes.

Barcia, P. L. (2006). Un inédito diccionario de argentinismos del siglo XIX. Buenos Aires: Academia Argentina de Letras.

Barclay Rey de Castro, F. (2009). El estado federal de Loreto, 1896: centralismo, descentralización y federalismo en el Perú a fines del siglo XIX. Lima: Tarea, Asociación Gráfica Educativa. https://doi.org/10.4000/books.ifea.776

Bazan, V. (2013). El federalismo argentino: situación actual, cuestiones conflictivas y perspectivas. Estudios constitucionales, 1(11), 37-88. https://doi.org/10.4067/S0718-52002013000100003

Beltrán, E. G., \& Graglia, J. E. (coords.) (2010). Federalismo argentino actual. Córdoba, República Argentina: Universidad Católica de Córdoba.

Calvillo, M. (2002). La república federal mexicana. Gestación y nacimiento. México DF: Colmex y Colsan.

Cantilo, J. M. (1868). El Federalista. Artículos sobre la Constitución de los Estados Unidos escritos en 1788 por Mr. Hamilton, Mr. Madison y Mr. Jay y correjidos por los mismos autores, con un apéndice que contiene los Artículos de la Confederación y la Constitución de los E.U. Buenos Aires: Imprenta del Siglo, Victoria 151.

Capellán de Miguel, G. (2011). La república Norte-Americana como modelo político para el krausismo español. Bulletin d'histoire contemporaine de l'Espagne, 46, 43-70.

Capellán de Miguel, G., \& Ayzagar, J. (2002). Federalismo. In Fernández Sebastián, J. \& Fuentes, J.F. (dirs.), Diccionario político y social del siglo XIX español. Madrid: Alianza, 305-310.

Carey, G. (1984). Selección de El Federalista. Estudios Públicos, 13, 1-2.

Carmagnani, M. (comp.) (1993). Federalismos latinoamericanos. México / Brasil / Argentina: F.C.E.

Chiaramonte, J. C. (1993). El Federalismo argentino en la primera mitad del siglo XIX. In Carmagnani, M. (comp.). Federalismos latinoamericanos. México / Brasil / Argentina: F.C.E.

Constitución de la Nación Argentina. Buenos Aires: Imprenta de la Nación Argentina, San Martín 124, 1868.

Constitución de la República de Chile jurada y promulgada el 25 de mayo de 1833. Chile: Imprenta de la Opinión, 1833), Art. $2^{\circ}-3^{\circ}$, Cap. I "De la forma de Gobierno".

Di Meglio, G. (2007). ;Viva el pueblo! La plebe urbana de Buenos Aires y la política entre la Revolución de Mayo y el rosismo. Buenos Aires: Prometeo.

Dietze, G. (1960). The Federalist: A Classic on Federalism and Free Government. Baltimore: The John Hopkins Press, I. 
Fernández Sebastián, J. (coord.). (2012). La aurora de la libertad. Los primeros liberalismos en el mundo iberoamericano. Madrid: Marcial Pons.

Fernández Sebastián, J. (dir.). (2009). Diccionario político y social del mundo iberoamericano. Madrid: Fundación Carolina / Sociedad Estatal de Conmemoraciones Culturales / Centro de Estudios Políticos y Constitucionales.

Fernández Sebastián, J., \& Fuentes, J. F. (dirs.) (2002), Diccionario político y social del siglo XIX español. Madrid: Alianza

García de Sena, M. (1811). La independencia de la costa firme justificada por Thomas Paine treinta años ha. Philadelphia.

García García, J. F. (2007). Tres aportes fundamentales de El Federalista a la teoría constitucional moderna. Revista de Derecho, 1 vol. 20, 39-59. https://doi.org/10.4067/S0718-09502007000100002

Gilmore, R. L. (1995). El federalismo en Colombia 1810-1859. Bogotá: Sociedad santanderista de Colombia, U. Externado de Colombia.

Goldman, N. (1998). Revolución, República y Confederación, t.3. Nueva Historia. Buenos Aires: Argentina.

Goldman, N. (2008). Lenguaje y Revolución. Conceptos políticos clave en el Río de la Plata, 1780-1850. Buenos Aires: Prometeo.

Goldman, N. (2010). Buenos Aires, 1810: la `revolución`, el dilemma de la legitimidad y de las representaciones de la soberanía del pueblo. Historia y Política, 24, 47-69.

Hamilton, A. (1788). The Federalist: A collection of essays, written in favour of the New Constitution, as agreed upon by the Federal Convention, September 17, 1787. New York: J. and A. M., Hanover-Square.

Hamilton, A. (1810). The Works of Alexander Hamilton: Comprising His Most Important Official Reports; an Improved Edition of the Federalist, on the New Constitution, Written in 1788; and Pacificus, on the Proclamation of Neutrality, Written in 1793. New York: Williams and Whiting.

Henry, B., \& Dawson, H. B. (1863). The Federalist. A collection of essays, written in favour of the new Constitution, as agreed upon by the Federal Convention, September 17, 1787. Reprinted from the original text. With an historical introduction and notes, H.B.D in two volumes. New York: Charles Scribner / London: Sampson Low, Son \& Co.

Hernández, A. H. (dir.). (2009). Aspectos históricos y políticos del federalismo argentino. Córdoba, Argentina: Academia Nacional de Derecho y Ciencias Sociales de Córdoba.

Hölscher, L. (2004). Hacia un diccionario histórico de los conceptos políticos europeos. Aportación teórica y metodológica de la Bregriffsgeschichte. Ayer 53, 97-108.

Isla, I. (1887). El Federalista. Escrito en 1788 por los Señores Hamilton, Madison y Jay sobre la nueva constitución con un apéndice que contiene las cartas de Pacificus y Helvidius sobre la proclamación de neutralidad en 1793, así como los artículos originarios de confederación y la constitución de los Estados Unidos. Buenos Aires: Establecimiento Tipográfico de la Pampa, Victoria 97 y 99.

James, K. (1865). Del gobierno y jurisprudencia constitucional de los Estados Unidos. Buenos Aires: Imprenta de Buenos aires.

Klauer, A. (2002). La República Federal de los Andes. Una propuesta de descentralización del Perú. Lima: Nueva Historia.

Laboulaye, E. (1870). Historia de los Estados Unidos: primera época, las colonias antes de la revolución 1620-1763 \& Historia de los Estados Unidos: la guerra de la independencia: 1763-1782. Sevilla: Eduardo Perié.

Laboulaye, E. (1871). Historia de los Estados Unidos: estudios sobre su constitución. Sevilla: Eduardo Perié.

Le fédéraliste: ou collection de quleques Écrits en faveur de la Constitution proposée aux États-Unis del'Amerique par la Convention convoquée en 1787 (Paris: Buisson, 1792).

Loayza, A., \& Aljovín de Losada, C. (2009). Federalismo. Perú. In Fernández Sebastián, Diccionario político y social del mundo iberoamericano. Madrid: Fundación Carolina / Sociedad Estatal de Conmemoraciones Culturales / Centro de Estudios Políticos y Constitucionales.

Memoria para la Biblioteca Nacional en el presente año, 1875. Madrid: Imprenta, Estereotipia y Galvanoplastia de Aribau y Ca.., Impresores de Cámara de S.M., 1875.

Norton Pomeroy, J. (1869). Poderes ejecutivos del gobierno de los estados-unidos. In An introduction to the constitutional law of the united-states. Buenos Aires: Imp. Lit. y Fund. De tipos a vapor. 
Ocampo López, J. (1979). La Independencia norteamericana y su repercusión en la independencia de Colombia. Caracas: Instituto Panamericano de Geografía e Historia, Comisión de Historia, Comité Orígenes de la Emancipación.

Portillo, J. M. (2009). Federalismo. España. In Fernández Sebastián, Diccionario político y social del mundo iberoamericano, Madrid: Fundación Carolina / Sociedad Estatal de Conmemoraciones Culturales / Centro de Estudios Políticos y Constitucionales.

Sagra, R. de la (1835). Cinco meses en los Estados Unidos de la América del Norte, la Colección de las varias cartas constitucionales que rigen Europa para instrucción de los españoles y comparación de unos códigos con otros. Carta constitucional francesa en 1830. Barcelona: Imprenta de M. Texero.

Souto, N. (2009). Federalismo. Argentina - Río de la Plata. In Fernández Sebastián, Diccionario político y social del mundo iberoamericano. Madrid: Fundación Carolina / Sociedad Estatal de Conmemoraciones Culturales / Centro de Estudios Políticos y Constitucionales.

Story, J. (1863). Breve esposicion de la constitucion de los Estados Unidos: para el uso de las clases superiores de las escuelas comunes, trans. José María Cantilo. Buenos Aires: Imprenta del Siglo.

Story, J. (1863). Poder judicial de los Estados Unidos de América: su organización y atribuciones: libro tercero de sus comentarios, trans. José María Cantilo. Buenos Aires: Imprenta del Siglo.

The Federalist: A collection of essays, written in favour of the New Constitution, as agreed upon by the Federal Convention, September 17, 1787, in two volumes. (1788). New York: J. and A. M., $\mathrm{n}^{\mathbf{0}} 41$ Hanover-Square.

Thibaud, C. (2009). Federalismo. Colombia. In Fernández Sebastián, J. Diccionario político y social del mundo iberoamericano. Madrid: Fundación Carolina / Sociedad Estatal de Conmemoraciones Culturales / Centro de Estudios Políticos y Constitucionales.

Vanossi, J. R. (1964). Situación actual del federalismo. Buenos Aires: Desalma.

Velasco, G. (1943). El federalista. México: Fondo de Cultura Económica

Viguera Ruiz, R. (2016). Referencias al federalismo norteamericano a partir de la primera traducción de El Federalista (1868). El caso argentino en el ámbito hispano. Investigaciones históricas, 36, 193-213.

Zoraida Vázquez, J. (1993). El federalismo mexicano, 1823-1847. In Federalismos latinoamericanos: México/Brasil/Argentina. México: Fondo de Cultura Económica-El Colegio de México, 15-50.

\section{Notes}

Note 1. Some initial thoughts on this idea in Viguera Ruiz, R. (2016). Referencias al federalismo norteamericano a partir de la primera traducción de El Federalista (1868). El caso argentino en el ámbito hispano. Investigaciones históricas, 36, 193-213.

Note 2. The original essays were printed in New York, in three different newspapers from 27 October, 1787, onwards: Independent Journal, New-York Packet and Daily Advertiser. On 19 September that same year the first copy of the North American Constitution was published in the Pennsylvania Packet.

Note 3. Carey, G. (1984). Selección de El Federalista. Estudios Públicos, 13, 1-2.

Note 4. Le fédéraliste: ou collection de quleques Écrits en faveur de la Constitution proposée aux États-Unis del'Amerique par la Convention convoquée en 1787 (Paris: Buisson, 1792).

Note 5. The Federalist: A collection of essays, written in favour of the New Constitution, as agreed upon by the Federal Convention, September 17, 1787, by Alexander Hamilton in two volumes (New York: J. and A. M., Hanover-Square, MDCCLXXXVIII). The two original first volumes in the Library of Congress http://www.loc.gov/ [12 March, 2019].

Note 6. Hamilton, A. (1810). The Works of Alexander Hamilton: Comprising His Most Important Official Reports; an Improved Edition of the Federalist, on the New Constitution, Written in 1788; and Pacificus, on the Proclamation of Neutrality, Written in 1793. New York: Williams and Whiting.

Note 7. Adair, D. (1974). Fame and the Founding Fathers. Indianapolis: Liberty Fund.

Note 8. Henry B. Dawson, H.B. (1863). The Federalist. A collection of essays, written in favour of the new Constitution, as agreed upon by the Federal Convention, September 17, 1787. Reprinted from the original text. With an historical introduction and notes, H.B.D in two volumes. New York: Charles Scribner / London: Sampson Low, Son \& Co.

Note 9. Among others, see the ones edited in Hallowell, 1857; Philadelphia, 1864 by Lippincott Company (re-ed. 1866, 1869); New York and London by G. P. Putnam, 1891 and 1895. 
Note 10. Diccionario del lenguaje argentino (Buenos Aires: Academia Argentina de Ciencias, Letras y Artes, 1875-1879) and Pedro Luis Barcia, Un inédito diccionario de argentinismos del siglo XIX (Buenos Aires: Academia Argentina de Letras, 2006).

Note 11. Fernández Sebastián, J. (dir.). (2009). Diccionario político y social del mundo iberoamericano. Madrid: Fundación Carolina / Sociedad Estatal de Conmemoraciones Culturales / Centro de Estudios Políticos y Constitucionales. Fernández Sebastián, J. (coord.). (2012). La aurora de la libertad. Los primeros liberalismos en el mundo iberoamericano. Madrid: Marcial Pons. \& Hernández, A.H. (dir.). (2009). Aspectos históricos y políticos del federalismo argentino. Córdoba, Argentina: Academia Nacional de Derecho y Ciencias Sociales de Córdoba.

Note 12. For the specific Argentinian case see, among others, Souto, N. (2009). Federalismo. Argentina - Río de la Plata. In Fernández Sebastián, Diccionario político y social del mundo iberoamericano, 459 and Hernández, Aspectos históricos y políticos del federalismo argentino. For Chilean case see Constitución de la República de Chile jurada y promulgada el 25 de mayo de 1833 (Chile: Imprenta de la Opinión, 1833), Art. 2-3', Cap. I "De la forma de Gobierno"; and Fernández Sebastián, J. (2009). Diccionario político y social del mundo iberoamericano, 479. To study the Colombian case see, among others, Thibaud, C. (2009). Federalismo. Colombia. In Fernández Sebastián, Diccionario político y social del mundo iberoamericano, 491; Ocampo López, J. (1979). La Independencia norteamericana y su repercusión en la independencia de Colombia. Caracas: Instituto Panamericano de Geografía e Historia, Comisión de Historia, Comité Orígenes de la Emancipación; \& Gilmore, R.L. (1995). El federalismo en Colombia 1810-1859. Bogotá: Sociedad santanderista de Colombia, U. Externado de Colombia. For Mexico see Ávila, A. (2002). En nombre de la Nación. La formación del gobierno representativo en México. México: CIDE Taurus; Ávila, A. (2002). Federalismo. México. In Fernández Sebastián, Diccionario político y social del mundo iberoamericano. Madrid: Fundación Carolina / Sociedad Estatal de Conmemoraciones Culturales / Centro de Estudios Políticos y Constitucionales; Calvillo, M. (2002). La república federal mexicana. Gestación y nacimiento. México DF: Colmex y Colsan; and Zoraida Vázquez, J. (1993). El federalismo mexicano, 1823-1847. In Federalismos latinoamericanos: México/Brasil/Argentina. México: Fondo de Cultura Económica-El Colegio de México, 15-50. To understand the case of Peru see Barclay Rey de Castro, F. (2009). El estado federal de Loreto, 1896: centralismo, descentralización y federalismo en el Perú a fines del siglo XIX. Lima: Tarea, Asociación Gráfica Educativa; Klauer, A. (2002). La República Federal de los Andes. Una propuesta de descentralización del Perú. Lima: Nueva Historia; or Loayza, A. \& Aljovín de Losada, C. (2009). Federalismo. Perú. In Fernández Sebastián, Diccionario político y social del mundo iberoamericano. For the peculiar case of Spain see Capellán de Miguel, G. \& Ayzagar, J. (2002). Federalismo. In Fernández Sebastián, J. \& Fuentes, J.F. (dirs.), Diccionario político y social del siglo XIX español. Madrid: Alianza, 305-310; and Portillo, J.M. (2009). Federalismo. España. In Fernández Sebastián, Diccionario político y social del mundo iberoamericano, 498-505.

Note 13. This Constitution is well known as C.N. 1853/1860. It has been in force up to the present day, suffering some constitutional reforms in 1866, 1898, 1957 and 1994.

Note 14. See works as Bazan, V. (2013). El federalismo argentino: situación actual, cuestiones conflictivas y perspectivas. Estudios constitucionales, 1 (11), 37-88; García García, J.F. (2007). Tres aportes fundamentales de El Federalista a la teoría constitucional moderna. Revista de Derecho, 1 vol. 20, 39-59; Beltrán, E.G. and Graglia, J.E. (coords.) (2010). Federalismo argentino actual. Córdoba, República Argentina: Universidad Católica de Córdoba; and Vanossi, J.R. (1964). Situación actual del federalismo. Buenos Aires: Desalma.

Note 15. Political and biographical notes in: http://apym.hcdn.gob.ar/expedientes [8.8.2016]

Note 16. He died on August 16, 1872.

Note 17. Story, J. (1863). Poder judicial de los Estados Unidos de América: su organización y atribuciones: libro tercero de sus comentarios, trans. José María Cantilo. Buenos Aires: Imprenta del Siglo, and Story, J. (1863). Breve esposicion de la constitucion de los Estados Unidos: para el uso de las clases superiores de las escuelas comunes, trans. José María Cantilo. Buenos Aires: Imprenta del Siglo.

Note 18. See his speech in Parliament: Diario de Sesiones del Congreso de los Diputados -Congressional Session's Dairy- (henceforth DSCD) 24 May 18629.

Note 19. Mr. Obligado, DSCD 7 August 1862410.

Note 20. DSCD 7 August 1862417.

Note 21. Ideas from Juan José Mármol and José María Cantilo, DSCD 11 June 1862133.

Note 22. DSCD 11 June 1862 and DSCD 13 June 1862 130-152.

Note 23. DSCD 18 June 1862168. 
Note 24. See the original The Federalist: A collection of essays, written in favour of the New Constitution, as agreed upon by the Federal Convention, September 17, 1787, in two volumes (New York: J. and A. M., n 41 Hanover-Square, MDCCLXXXVIII).

Note 25. Cantilo claimed this structure and additions to be the same as in the work of García de Sena, M. (1811). La independencia de la costa firme justificada por Thomas Paine treinta años ha. Philadelphia.

Note 26. Dietze, G. (1960). The Federalist: A Classic on Federalism and Free Government. Baltimore: The John Hopkins Press, I.

Note 27. Hölscher, L. (2004). Hacia un diccionario histórico de los conceptos políticos europeos. Aportación teórica y metodológica de la Bregriffsgeschichte. Ayer 53, 97-108. Suggested readings on Argentinian federalism: Chiaramonte, J.C. (1993). El Federalismo argentino en la primera mitad del siglo XIX. In Carmagnani, M. (comp.). Federalismos latinoamericanos. México / Brasil / Argentina: F.C.E.; Di Meglio, G. (2007). ¡Viva el pueblo! La plebe urbana de Buenos Aires y la política entre la Revolución de Mayo y el rosismo. Buenos Aires: Prometeo; or several Works of Noemí Goldman such as: (2010). Buenos Aires, 1810: la 'revolución', el dilemma de la legitimidad y de las representaciones de la soberanía del pueblo. Historia y Política, 24, 47-69; (1998). Revolución, República y Confederación, t.3. Nueva Historia. Buenos Aires: Argentina; (2008). Lenguaje y Revolución. Conceptos políticos clave en el Río de la Plata, 1780-1850. Buenos Aires: Prometeo.

Note 28. Cantilo, J.M. (1868). El Federalista. Artículos sobre la Constitución de los Estados Unidos escritos en 1788 por Mr. Hamilton, Mr. Madison y Mr. Jay y correjidos por los mismos autores, con un apéndice que contiene los Artículos de la Confederación y la Constitución de los E.U. Buenos Aires: Imprenta del Siglo, Victoria 151, I.

Note 29. Cantilo, El Federalista, III.

Note 30. Reflections from Annabel Brett, New Directions of Political Thoughts. Political concepts and thoughts (talk in New York University, New York, 13 March 2014).

Note 31. Cantilo, El Federalista, I-II.

Note 32. Gazeta de Buenos Ayres, "Sobre federaciones," 30 March 1816. See for the complete reference Souto, Federalismo. Argentina, 451-461.

Note 33. Isla, I. (1887). El Federalista. Escrito en 1788 por los Señores Hamilton, Madison y Jay sobre la nueva constitución con un apéndice que contiene las cartas de Pacificus y Helvidius sobre la proclamación de neutralidad en 1793, así como los artículos originarios de confederación y la constitución de los Estados Unidos. Buenos Aires: Establecimiento Tipográfico de la Pampa, Victoria 97 y 99.

Note 34. Velasco, G. (1943). El federalista. México: Fondo de Cultura Económica.

Note 35. DSCD 29 July 1868 189-190. See the printed work Diario de Sesiones de la Cámara de Diputados. Año de 1868 (Buenos Aires: Imprenta del Porvenir, Defensa 139, 1879).

Note 36. DSCD 4 September 1868273.

Note 37. DSCD 27 May 1868 30, DSCD 1 June 1868 41, DSCD 22 June 1868 99, and DSCD 23 September 1868395.

Note 38. Latter Spanish versions of these works: Norton Pomeroy, J. (1869). Poderes ejecutivos del gobierno de los estados-unidos. In An introduction to the constitutional law of the united-states. Buenos Aires: Imp. Lit. y Fund. De tipos a vapor; James, K. (1865). Del gobierno y jurisprudencia constitucional de los Estados Unidos. Buenos Aires: Imprenta de Buenos aires; Laboulaye, E. (1871). Historia de los Estados Unidos: estudios sobre su constitución. Sevilla: Eduardo Perié, and Laboulaye, E. (1870). Historia de los Estados Unidos: primera época, las colonias antes de la revolución 1620-1763 \& Historia de los Estados Unidos: la guerra de la independencia: 1763-1782. Sevilla: Eduardo Perié.

Note 39. Several changes occurred by that time in the Constitution of Argentina. See Constitución de la Nación Argentina (Buenos Aires: Imprenta de la Nación Argentina, San Martín 124, 1868).

Note 40. Capellán de Miguel, G. (2011). La república Norte-Americana como modelo político para el krausismo español. Bulletin d'histoire contemporaine de l'Espagne, 46, 43-70. Capellán states that other works were more widely circulated in Spain from the beginning of the 19th century. See, for instance, Sagra, R. de la (1835). Cinco meses en los Estados Unidos de la América del Norte, la Colección de las varias cartas constitucionales que rigen Europa para instrucción de los españoles y comparación de unos códigos con otros. Carta constitucional francesa en 1830. Barcelona: Imprenta de M. Texero, and Angulo y Heredia, A. (1865). Estudios sobre los Estados Unidos de América Revista Hispano Americana.

Note 41. Capellán de Miguel, "La república Norte-Americana como modelo político para el krausismo español,” 19. 
Note 42. Memoria para la Biblioteca Nacional en el presente año, 1875 (Madrid: Imprenta, Estereotipia y Galvanoplastia de Aribau y Ca., Impresores de Cámara de S.M., 1875).

\section{Copyrights}

Copyright for this article is retained by the author(s), with first publication rights granted to the journal.

This is an open-access article distributed under the terms and conditions of the Creative Commons Attribution license which permits unrestricted use, distribution, and reproduction in any medium, provided the original work is properly cited. 